\title{
NIKE ON INSTAGRAM: THEMES OF BRANDED CONTENT AND THEIR ENGAGEMENT POWER
}

\author{
Carmen Balan ${ }^{1}$
}

\begin{abstract}
Instagram is the fastest developing new media of high interest to marketers. As at December 21, 2016, the community included 600 million Instagrammers. This paper explores the problem of whether various themes of branded content differ significantly in their engagement power (ability to generate likes, views, and comments). The methodological approach consists of online monitoring of content in posts of a leading brand, Nike, for its 17 verified-badge Instagram accounts. The study focused on posts during the month of February 2017. The chi-square goodness of fit test (for one variable) was applied in the data analysis stage of the research. The initial hypothesis of significant differences between branded content themes as regards their engagement power was accepted. The practical implications of these findings for marketers include better selection of brand messages for Instagrammers and an increase in engagement levels.
\end{abstract}

JEL Classification Numbers: M30, M31 DOI: http://dx.doi.org/10.12955/cbup.v5.894

Keywords: Instagram, branded content, engagement, likes, views, comments, followers

\section{Introduction}

The dynamics of Instagram reveals one of the most rapid growth areas among social media. Instagram first launched on October 6, 2010. The interest in this new communication channel was overwhelming. The first day had 25000 people signing for membership (Instagram, 2010, October 6). According to the 2016 press news of Instagram (2016, December 21), 100 million people had joined the community by the end of the second semester of 2016. The same source reported the number of Instagrammers had then surpassed 600 million members.

Nike is a highly recognizable consumer brand present on Instagram. It is a leading brand in the global sportswear market with a market share that was worth 17.2\% in 2015 (Euromonitor International, 2016). The brand consistently held the leading position in every year of 2010-2015. According to the report published by Interbrand in 2016, this brand ranks eighteenth in the Top 100 best global brands and its market value reached USD 25034 mil. (Interbrand, 2016). As a comparison, one of its strongest competitors, Adidas, ranks sixtieth in the same top 100, with a brand value of USD 7885 mil.

This paper presents the findings of research into the engagement power of branded content themes of Instagram posts. The Nike brand was chosen for this purpose because of its global ranking, as mentioned above. To the best of the author's knowledge, this research has two unique features compared to studies with findings published in academic literature: 1) the present research is the first to address the topic of the engagement power of branded content themes on Instagram, and 2) it is the first to focus on Instagram posts of a leading brand such as Nike.

\section{Literature Review}

Since its launch in 2010, Instagram has not gained a high status as a priority field of study for academic researchers. A search of the Thomson Reuters database, Web of Science Core Collection, on March 19, 2017, using the keyword 'Instagram' as a research topic, revealed a total of 353 published studies, of which 165 were articles. A search of the same database using the same keyword, this time as a 'title,' revealed 90 results of which 44 were articles. These numbers indicated an opportunity for designing and implementing a future study relating to Instagram as a communication tool used by individuals and companies.

Many of the 90 title results were studies in categories that were related to computer science. The business, management, and economics categories of the academic literature had a lower contribution to the academic literature focused on Instagram topics. The vast majority of studies relating to Instagram focused mainly on the use of this tool by individuals and to a lesser extent by companies. Those relating to the content posted by brands on Instagram were uncommon. Consequently, the findings relative to the branded content posted on another online social media site, Facebook, were used to form the hypothesis for the current research paper relating to Instagram.

\footnotetext{
${ }^{1}$ The Bucharest University of Economic Studies, carmen.balan @ mk.ase.ro
} 
Lee et al. (2015) identified five primary social and psychological motives for using Instagram. Based on the findings of a survey of Instagram users, the main motives were the following: social interaction, archiving, self-expression, escapism, and peeking. Instagrammers seem to use the platform to escape from their everyday lives and connect with friends, family members, and other people via an online realm of existence.

Instagram has provided brands with a social media platform for visual communication with their target market. Various brands have experimented with the viral marketing of content in the form of videos. Examples include the brands of the fashion sector, especially the luxury brands (Wolny \& Mueller, 2013). Brand-sponsored videos aim to attract the attention of visual influencers and to engage the target customers. Within the fashion sector, major brands such as Zara, Mango, and El Corte Ingles actively use social media as a communication channel (Gonzalez, 2015).

Many research studies of Facebook show that this type of brand content influences engagement on that particular site. Examples of such studies are those carried out by Taylor et al. (2011); De Vries et al. (2012); Chauhan and Pillai (2013); and Tafesse (2015).

Beukeboom et al. (2015) found that brand evaluations may improve with audience exposure to Facebook posts. However, their findings underlined that exposure to more of the same content does not generate a difference in terms of brand evaluations.

The study of Coelho et al. (2016), which related to 680 Facebook posts and 1169 posts on Instagram, measured the effect of post type (advertising, fan, events, information, and promotion) on audience likes and comments. The findings disclosed that post types focusing on events and promotion led to a higher involvement of followers, especially on Instagram.

According to the findings of Jahn and Kunz (2012), valuable content, either functional or hedonic, is an important driver that attracts users to fan-pages. Based on their research, the content must be interesting, entertaining, and innovative to be impactful.

Luarn et al. (2015) found that the type of post content (information, entertainment, remuneration, and social) of brand pages on Facebook significantly influenced the engagement of users. They found that the post content that focused on entertainment generated higher levels of commenting and sharing than other types.

The survey by Yuki (2015) showed that, on Facebook and other social media sites, the posts that were shared the most were those that conveyed the emotion of happiness. In addition, the content that involved usefulness increased the sharing likelihood among women and people over 55 years.

The various research findings relating to social media such as Facebook has led to the conclusion that branded content type influences engagement. These results lead to the hypothesis that Instagram content themes will differ in the engagement that they generate among followers.

\section{Data and Methodology}

The aim of this research was to determine whether various themes of branded content were significantly different in their engagement power (ability to generate likes, views, and comments). The initial hypothesis was as follows: there are significant differences between various themes of branded content in regards to their engagement power. The research focused on the Nike accounts existing on Instagram. The method of data collection involved observations of the online environment.

The scope of this research involved themes corresponding to the branded content posted by Nike, not by consumers and fans in their Instagram accounts. Thus, accounts were carefully selected to avoid systematic errors due to unclear ownership of the various ones that focused on Nike Sportswear on Instagram. The selection of each account was based on proof of ownership by Nike. This proof was the existence of a verified badge on the Instagram account associated with a Nike theme. A total of 20 verified-badge Instagram accounts resulted from the selection process.

Data of all photo and video posts by the Nike brand during the interval February 1-28, 2017 were collected by observing each verified-badge Instagram account. From the 20 verified-badge Instagram accounts of Nike, only 17 had content posted during February 2017. The three accounts that had no posts during this month were Nike Lab, Nike Toronto, and Nike Young Athletes.

In the case of each post, the following data were monitored: the theme of the branded content, the number of likes (for photo posts), the number of views (for video posts), and the number of comments 
(associated with both photo and video posts). The themes were defined by qualitative analysis of the post content. Thus, the themes were not pre-defined before the design of the study, but they were developed during the research process, based on results of content monitoring of posts by the Nike brand. In the case of the video posts, the online monitoring included viewing the content for theme identification.

A total number of 121 posts in the study interval of February 2017 were recorded for the 17 verifiedbadge Instagram accounts of Nike. These were analyzed in terms of engagement power. In essence, the indicator 'engagement power of a post' was the sum of all reactions generated by that specific post among the Instagram followers. In the case of a photo post, the engagement power was reflected by the number of likes and comments, while in the case of a video post, the number of views and comments indicated the engagement power. Overall, the engagement power of a branded content theme was the sum of likes, views, and comments generated by the Nike brand followers.

A database was created to ensure a systematic approach to data collection from online monitoring. For each post, both qualitative and quantitative information were registered. Qualitative information consisted of the type of post (photo or video) and the theme of the post content. Quantitative information included entries relating to the number of likes, views, and comments generated by each post. Evidence of the posts was kept chronologically according to the date of the post.

Data were analyzed using the chi-square goodness of fit test (with one variable). This test determines whether certain models fit the observed data (Malhotra, 2010). The value of $X^{2}$ was calculated as follows:

$$
X^{2}=\Sigma\left[\left(E P_{o}-E P_{e}\right)^{2} / E P_{e}\right]
$$

where:

$$
\begin{aligned}
& E P_{o}=\text { engagement power resulted from observation, and } \\
& E P_{e}=\text { expected engagement power. }
\end{aligned}
$$

\section{Results and Discussion}

The metrics for content posted on 17 verified-badge Instagram accounts of the brand Nike are listed in Table 1.

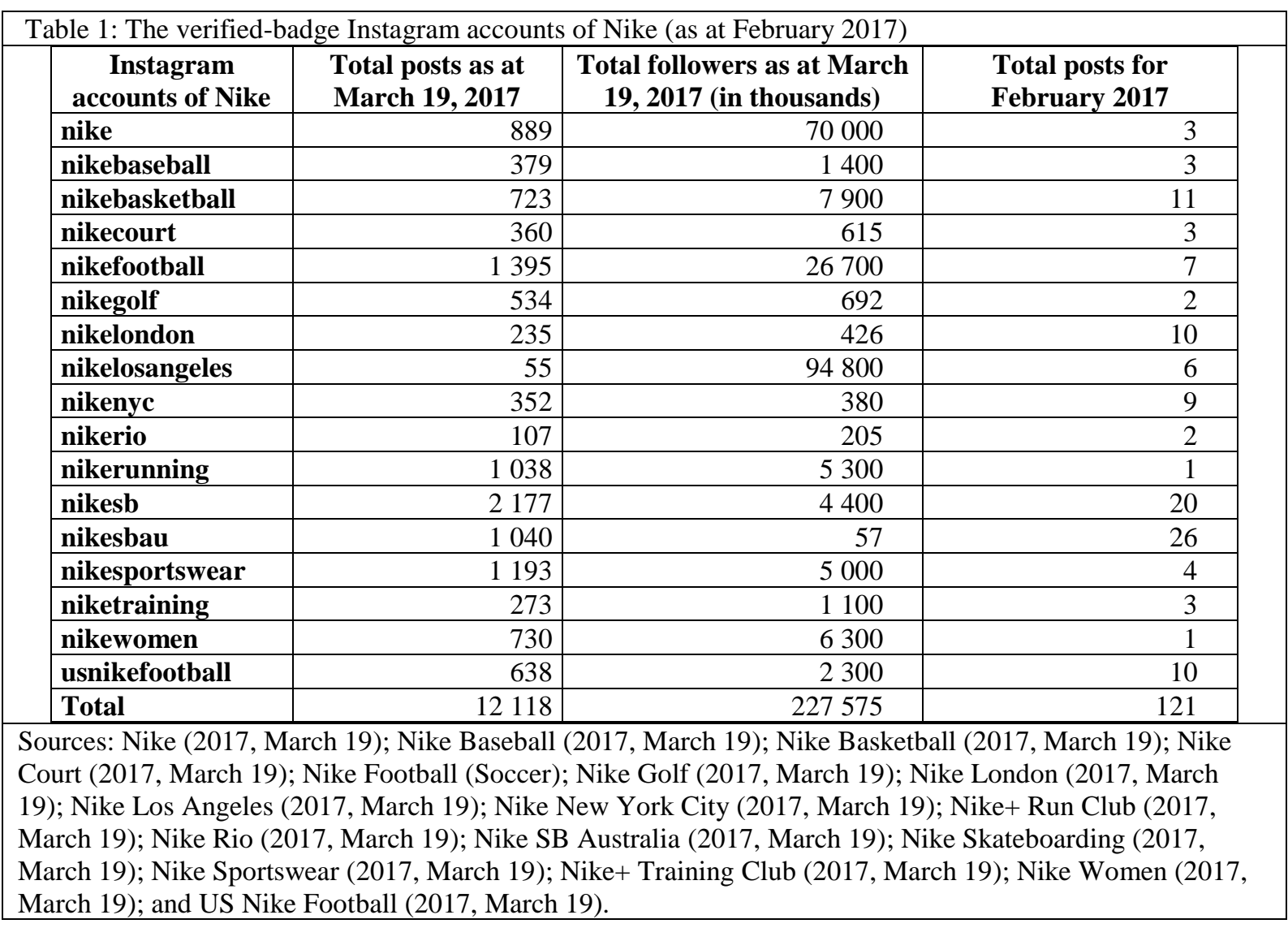


On March 19, 2017, the studied accounts reached a total of 12118 posts by Nike (since the date of the setting-up of each account). The total of followers of these accounts was 227.57 million.

Some accounts were more active than others, from the perspective of the total number of posts. Five of the 17 accounts received $56.5 \%$ of the total posts. These accounts were nikesb, nikefootball. nikesportswear, nikesbau, and nikerunning.

In February 2017, the 121 photo and video posts to the 17 verified-badge Instagram accounts generated an engagement level consisting of 9247138 likes, views, and comments (Table 2). The average engagement power per post was 76423 likes, views, and comments. This statistic varied among the content themes presented by the photo and video posts on the verified-badge Instagram accounts. The strongest posts in terms of engagement power were related to those of user experience (194 350 likes, views, and comments), while the weakest were those relating to sport and style or fashion (3365 likes, views, and comments).

\begin{tabular}{|c|c|c|c|}
\hline Brand content theme & Number of posts & $\begin{array}{l}\text { Total engagement power } \\
\text { of the theme }\end{array}$ & $\begin{array}{l}\text { Average engagement } \\
\text { power per post }\end{array}$ \\
\hline Art and sport & 4 & 297457 & 74364 \\
\hline Aspirational values & 30 & 3890330 & 129678 \\
\hline Branded product & 23 & 1219324 & 53014 \\
\hline Sports and style/ fashion & 3 & 10096 & 3365 \\
\hline Sports competitions & 11 & 1013265 & 92115 \\
\hline Sports people in action & 42 & 1261870 & 30045 \\
\hline User experience & 8 & 1554796 & 194350 \\
\hline Total & 121 & 9247138 & 76423 \\
\hline
\end{tabular}

In the month of February 2017, the aspiration values, itemized in Table 3, pertained primarily to 'equality' as communicated by Nike. The result of chi-square goodness of fit test on the engagement power expected and observed are presented in Table 3.

Table 3: Observed $\left(\mathrm{EP}_{\mathrm{o}}\right)$ and expected $\left(\mathrm{EP}_{\mathrm{e}}\right)$ likes, views, and comments (in thousands) of Nike brand themes and the results of the chi-square tests

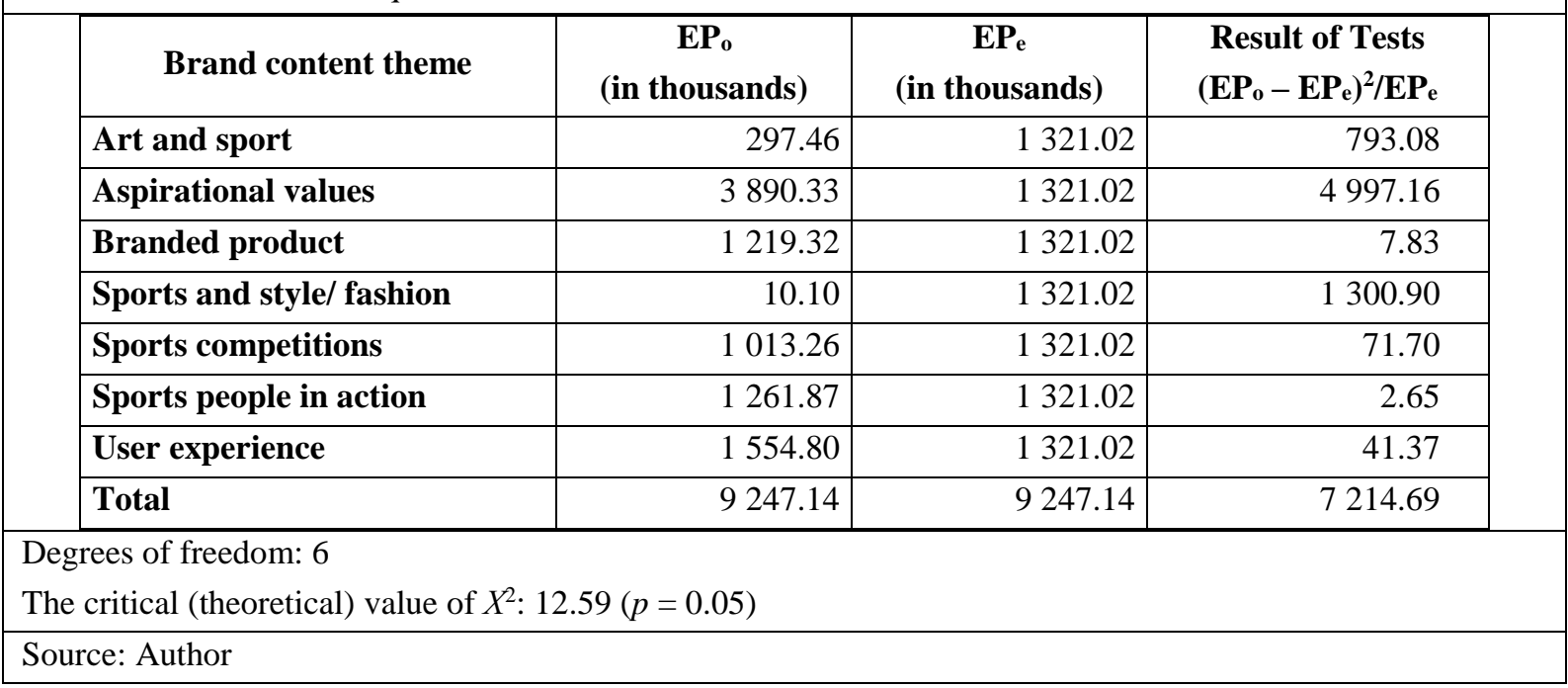

The comparison between the critical (theoretical) and calculated value of the chi-square statistic showed that the calculated overpassed the critical value. Thus, the null hypothesis that the observed and the expected were the same was rejected. Therefore, the results indicate the differences between content themes regarding their engagement power shown were statistically significant. 
The research results present a twofold perspective for discussion. The first pertains to previous research findings for Instagram; and the second about the existing research into Facebook as a major social media with high popularity. Relating to Instagram, the results of this study align with the findings of Coelho et al. (2016), according to the types of posts differing in the level of engagement they generate. Relating to Facebook, the findings of the research presented in this paper are similar to those of Luarn et al. (2015) and Yuki (2015) in regards to the different impact of post types. At the same time, there are similarities with the findings of Taylor et al. (2011); De Vries et al. (2012); Chauhan and Pillai (2013); and Tafesse (2015), from the viewpoint of brand content type influencing engagement, as in the case of Facebook.

\section{Conclusion}

The findings of this study revealed statistically significant differences between the content themes of Instagram posts by the brand, Nike. In addition, content that focused on user experience and aspirational values appeared to have more engagement power than other themes approached by Nike. The implications of these findings for the research domain is that they lead to more detailed studies of the engagement power of themes of branded content. The present study focused only on the posts of the brand, Nike. Further research could consider the engagement power of themes corresponding to posts of competing brands or by brands from other markets. In this respect, several new research questions arise. Examples include: Do the posts focused on user experience always have more engagement power compared to all other branded content themes? What aspirational values have the highest engagement power? Does the engagement power of a specific theme differ among the brands existing in the same sector? Is the engagement power dependent on the share held by the theme in the total number of posts made by the brand on various themes? Is the engagement power of a theme influenced by the type of product or market? How does the execution of each photo or video post influence significantly the engagement power? For practitioners, this study shows that impactful Instagram strategies that generate high levels of engagement require careful selection of branded content themes. Based on the present findings, practitioners are recommended to favor posts referring to user experience, aspirational value, and sports competitions, rather than posts focused on branded product. The brands present in the Instagram community need to be creative and differentiate their content not only from competitors but also between accounts. The number of Instagrammers is increasing rapidly. Undoubtedly, their expectations will evolve and continue to challenge the creativity of brands in more engaging and memorable experiences.

\section{References}

Beukeboom, C.J., Kerkhoff, P., \& de Vries M. (2015). Does a Virtual Like Cause Actual Liking? How Following a Brand's Facebook Updates Enhances Brand Evaluations and Purchase Intention. Journal of Interactive Marketing, 32, 26-36. doi: 10.1016/j.intmar.2015.09.003

Chauhan, K., \& Pillai, A. (2013). Role of content strategy in social media brand communities: A case of higher education institutes in India. Journal of Product and Brand Management, 22(1), 40-51. doi:10.1108/10610421311298687

Coelho, R.L.F., de Oliveira, D.S., \& de Almeida, M.I.S. (2016). Does social media matter for post typology? Impact of post content on Facebook and Instagram metrics. Online Information Review, 40(4), 458 - 471. doi:10.1108/OIR-06-2015-0176

De Vries, L., Gensler, S., \& Leeflang, P.S.H. (2012). Popularity of brand posts on brand fan pages: An investigation of the effects of social media marketing. Journal of Interactive Marketing, 26(2), 83-91. doi:10.1016/j.intmar.2012.01.003

Euromonitor International. (2016). Apparel and Footwear. Nike Inc. Passport. Retrieved from

http://www.portal.euromonitor.com/portal/analysis/tab\#

Gensler, S., Volckner, F., Liu-Thompkins, Y., \& Wiertz, C. (2013). Managing Brands in the Social Media Environment. Journal of Interactive Marketing, 27(4), 242-256. doi: 10.1016/j.intmar.2013.09.004

Gonzalez, M.A. (2015). Las redes sociales como canal de comunicación de las marcas de moda españolas. El caso de Zara, Mango y El Corte Inglés. index l comunicación, 5(1), 77-105.

Instagram. (2010, October 6). Instagram Launches. Retrieved from https://instagram-press.com/2010/10/06/instagramlaunches-2/

Instagram. (2016, December 21). 600 Million and Counting. Retrieved from https://instagram-press.com/2016/12/21/600million-and-counting/

Interbrand. (2016). Best Global Brands 2016 Rankings. Retrieved from http://interbrand.com/best-brands/best-globalbrands/2016/ranking/

Jahn, B., \& Kunz, W. (2012). How to transform consumers into fans of your brand. Journal of Service Management, 23(3), 344-361. doi:10.1108/09564231211248444 
Lee, E., Lee, J.A., Moon, J.H., \& Sung, Y. (2015). Pictures Speak Louder than Words: Motivations for Using Instagram. Cyberpsychology Behavior and Social Networking, 18(9), 552-556. doi:10.1089/cyber.2015.0157

Luarn, P., Lin, Y.-F., \& Chiu, Y.-P. (2015). Influence of Facebook brand-page posts on online engagement. Online Information Review, 39(4), 505-519. doi:10.1108/OIR-01-2015-0029

Malhotra, N.K. (2010). Marketing research: An applied orientation: Global Edition. $6^{\text {th }}$ edition. Upper Saddle River, N.J.: Pearson Education.

Nike. (2017, March 19). nike. Retrieved from https://www.instagram.com/nike/

Nike Baseball. (2017, March 19). nikebaseball. Retrieved from https://www.instagram.com/nikebaseball/

Nike Basketball. (2017, March 19). nikebasketball. Retrieved from https://www.instagram.com/nikebasketball/

Nike Court. (2017, March 19). nikecourt. Retrieved from https://www.instagram.com/nikecourt/

Nike Football (Soccer). (2017, March 19). nikefootball. Retrieved from https://www.instagram.com/nikefootball/

Nike Golf. (2017, March 19). nikegolf. Retrieved from https://www.instagram.com/nikegolf/

Nike Lab. (2017, March 19). Nikelab. Retrieved from https://www.instagram.com/nikelab/

Nike London. (2017, March 19). nikelondon. Retrieved from https://www.instagram.com/nikelondon/

Nike Los Angeles. (2017, March 19). nikelosangeles. Retrieved from https://www.instagram.com/nikelosangeles/

Nike New York City. (2017, March 19). nikenyc. Retrieved from https://www.instagram.com/nikenyc/

Nike+ Run Club. (2017, March 19). Retrieved from https://www.instagram.com/nikerunning/

Nike Rio. (2017, March 19). nikerio. Retrieved from https://www.instagram.com/nikerio/

Nike SB Australia. (2017, March 19). nikesbau. Retrieved from https://www.instagram.com/nikesb

Nike Skateboarding. (2017, March 19). nikesb. Retrieved from https://www.instagram.com/nikesb/

Nike Sportswear. (2017, March 19). nikeportswear. Retrieved from https://www.instagram.com/nikesportswear/

Nike Toronto. (2017, March 19). niketoronto. Retrieved from https://www.instagram.com/niketoronto/

Nike+ Training Club. (2017, March 19). niketraining. Retrieved from https://www.instagram.com/niketraining/

Nike Women. (2017, March 19). nikewomen. Retrieved from https://www.instagram.com/nikewomen/

Nike Young Athletes. (2017, March 19). nikeyoungathletes. Retrieved from https://www.instagram.com/nikeyoungathletes/

Tafesse, W. (2015). Content strategies and audience response on Facebook brand pages. Marketing Intelligence \& Planning, 33(6). 927-943. doi:10.1108/MIP-07-2014-0135

Taylor, D.G., Lewin, J.E., \& Strutton, D. (2011). Friends, fans, and followers: Do ads work on social networks? How gender and age shape receptivity. Journal of Advertising Research, 51(1), 258-275. doi:10.2501/JAR-51-1-258-275

US Nike Football. (2017, March 19). usnikefootball. Retrieved from https://www.instagram.com/usnikefootball/

Yuki, T. (2015). What Makes Brands' Social Content Shareable on Facebook? An Analysis that Demonstrates The Power of Online Trust and Attention. Journal of Advertising Research, 55(4), 458-470. doi:10.2501/JAR-2015-026

Wolny, J., \& Mueller, C. (2013). Analysis of fashion consumers' motives to engage in electronic word-of-mouth communication through social media platforms. Journal of Marketing Management, 29(5-6), 562-583.

doi:10.1080/0267257X.2013.778324 